\title{
Bioactive Components in Breeding Industrial Tomato
}

\author{
Nenad Pavlović1 · Jelena Mladenović ${ }^{2} \cdot$ Radoš Pavlović $^{2}$. \\ Đorđe Moravčevićc ${ }^{3}$ Jasmina Zdravkovićí \\ IInstitute for Vegetables, Karađorđeva 71, 11420 Smederevska Palanka, Serbia \\ 'University of Kragujevac, Faculty of Agronomy in Čačak, Cara Dušana 34, 32000 Čačak, Serbia \\ ${ }^{3}$ University of Belgrade, Faculty of Agriculture in Zemun, Nemanjina 6, 11080 Belgrade - Zemun, Serbia
}

\begin{abstract}
Summary: Selection of tomato lines for industrial use regarding their nutritional value is a potential that will reflect in the final product obtained from tomato fruits. At the same time, technological process of preparation of tomato juice $\left(100{ }^{\circ} \mathrm{C}\right)$, as well as hot air drying, was studied in order to establish an optimal technological process that is the least disrupting for the natural potential of nutrients contained in fresh fruits. The research was performed on 6 lines and one variety of industrial tomato. The content of vitamin C, vitamin E, lycopene, $\beta$-carotene, phenols, flavonoids, dry matter and total antioxidative capacity was studied by applying standard methods for determination of the level of these parameters. Grouping was performed according to traits of average carotenoid content (lycopene, $\beta$-carotene), vitamin $\mathrm{C}$, vitamin $\mathrm{E}$, phenols, flavonoids, dry matter and total antioxidative capacity in tomato fruit, by applying PCA. The first two principle components were responsible for $77.18 \%$ of total variability of researched samples. The impact of other five components was low and they were responsible for $22.18 \%$ of the variability. Antioxidative activity was best preserved after finishing, through small losses of lycopene and $\beta$-carotene. Losses of vitamin $\mathrm{C}$, vitamin $\mathrm{E}$, phenols and flavonoids during thermal processing were great, mostly in juice, while in dried product, these losses were lower. Nutrient losses were in function of temperature height that the fruits were exposed to during the thermal processing. Genotypes SPRZ and SPSM were marked as the best.

Key words: industrial tomato, selected lines, PCA, nutrients, antioxidative activity
\end{abstract}

\section{Introduction}

Tomato was identified as a functional (nutraceutical) food (Canene-Adams et al., 2005). Identification of biologically active components in food impacts the healthy state of the organism and can decrease the risk of some diseases. The research of the content of bioactive components, especially the content of lycopene includes wide studies both in conventional breeding and in biotechnological research, with special with reference to possibility of an increase of its content (Tedeschi et al. 2011). High consumption of tomato in the world throughout the year makes it one of the main sources of minerals, vitamins and antioxidants. Traits that define originality of variety represent the gathering of a large number of traits, usually polygene, that correlate among themselves and create an identity of a genotype (Basavaraja and Hulamani, 2001).

Selection of tomato lines for industrial proceeding, for traits that define nutritive value, represent the

Corresponding author:

jzdravkovic@institut-palanka.co.rs

Acknowledgements:

This study was supported by the Serbian Ministry of Education, Science and Technological Development: Projects No. TR31059 (Integrating biotechnology approach in breeding vegetable crops for sustainable agricultural systems). potential that will be reflected in final product obtained from tomato fruits. Therefore it is fundamental to choose lines with high nutritional potential, so the future product has high nutritional and antioxidative value which directly impacts the health benefit. The chemical compound of tomato fruits is impacted by numerous factors such as genetic (variety), environment (light, temperature, mineral nutrition) and cultural practices (ripening stage at harvest, irrigation), Periago et al., (2009), Garcia-Valeverde et al., (2013). At the same time, an optimal technological process that will be the least destructive to natural potential in fresh fruits needs to be established. The predominant technology in the processing fruits is exposure to higher temperatures: slightly lower for drying and higher during cooking (pasteurization). Correlation of some nutrients with high temperature was different. Davey et al. (2000) proved that colder treatment and lower temperature of fruit processing impact the better preservation of vitamin $C$. The increase of nutritive quality of proceeded tomato with a high level of vitamin $\mathrm{C}$ is always desirable aim (Ruggieri et al., 2016)

During processing, a biological value can be improved regarding the level of carotenoids (lycopene and $\beta$-carotene) which depended on applied processing technology. For drying with hot air, temperatures should not increase $80^{\circ} \mathrm{C}$. Among bioactive compounds present 
in tomato, carotenoids, and especially level of lycopene appear as a factor that can be used for increasing commercial values of tomato fruits (Frusciante et al., 2007).

Tomato polyphenols are usually phenol acids (Frusciante et al., 2007). Quantity and composition of phenol compounds present in fruits depend on genotype, the storage conditions (Asami et al., 2003), the process of the extraction in the processing process (Hinneburg and Neubert, 2005; Mukhopadhyay et al., 2006), and environmental conditions (Caldwell et al., 2005). Vitamin $E$ has a beneficial effect on some types of cancer. Some studies indicate a high level of vitamin $\mathrm{E}$ in products obtained by thermal treatment of tomato (Pék et al., 2014, Abushita et al., 2000, Seybold et al., 2004).

Proper selection of appropriate genotypes and final phases of selection depend on the grouping of genotypes according to traits important for the general and specific aims of tomato selection (Foolad, 2007). Tomato selection requires a mutual understanding of a large number of traits, both morphological traits and chemical compound (Ganeva et al., 2006) on the genetically divergent material.

The main purpose of this research is to determine the level of bioactive components $(\beta$-carotene, lycopene, vitamin $E$, vitamin $C$, phenols and flavonoids) in genetically clean lines of industrial tomato in last phases of selection cycles. The level of bioactive components will represent breeding criteria for choosing lines for commercial hybrids in this type of tomato.

\section{Material and Method}

\section{Plant material}

A Comparative trial was set with 7 genotypes (one commercial variety (SP-109) and 6 selected lines (SPP, SPSM, SPRZ, SPRM-20, S-60 and SPO) - high inbreeding generation). The origin of clear lines was from different industrial tomato selection programs. The trial was set using standard methods of growing an industrial tomato, in a random block system, with three repetitions. Mature fruits were picked when they reached full color (45 days from pollination).

The level of lycopene, vitamin $C, \beta$ carotene, phenols and flavonoids in fresh fruits, dried fruits (drying with parallel hot air dryer at $60{ }^{\circ} \mathrm{C}$, until the final product obtains moisture smaller than $10 \%$ (Correia et al., 2015) and in tomato juice (pasteurization at $100{ }^{\circ} \mathrm{C}$ for 7 minutes) was studied.

\section{Determination of vitamin $C$}

Pale tomato juice was obtained by pressing $100 \mathrm{~cm}^{3}$ of tomato juice and $100 \mathrm{~g}$ of fresh or dry tomato and mixed with equal quantity of $\left(100 \mathrm{~cm}^{3}\right)$ solution of a mixture of $\mathrm{HPO}_{3}$ and glacial acid $\mathrm{CH}_{3} \mathrm{COOH}$. Then, the mixture was filtrated through creased filter paper. The first $5-10 \mathrm{~cm}^{3}$ of filtrated mixture was thrown away and the aliquot part was taken from the rest of the mixture for the further investigation. If necessary, the investigated sample was diluted with cooked, cooled distilled water, so the aliquot part contained about $2 \mathrm{mg}$ of ascorbic acid. The process of determining ascorbic acid in the sample: - $10 \mathrm{~cm}^{3}$ of filtrated sample (containing $5 \mathrm{~cm}^{3}$ of juice and $5 \mathrm{~cm}^{3} \mathrm{HPO}_{3}$ and glacial acid $\mathrm{CH}_{3} \mathrm{COOH}$ ) was applied to three Erlenmeyer dishes using pipette. Each sample was titrated with Tilmans reagent (TR) solution until pale pink, for about 5 seconds. At the same time, solution of TR was titrated and blind tested until pale pink (Cvijović \& Aćamović, 2005).

The content of ascorbic acid $\left(\mathrm{mg} / \mathrm{cm}^{3}\right)=\left(\mathrm{V}-\mathrm{V}_{1}\right) \times \mathrm{T}$ $\mathrm{x} 100 / \mathrm{g}$

$\mathrm{V}-\mathrm{cm}^{3}$ of TR solution used for titration in trial testing $\mathrm{V} 1-\mathrm{cm}^{3}$ of TR solution used in blind testing T- titer solution TR ( $\mathrm{mg} \mathrm{C}_{6} \mathrm{H}_{8} \mathrm{O}_{6} / 1 \mathrm{~cm}^{3}$ TR solution) $\mathrm{g}$ - juice volume in $\mathrm{cm}^{3}$ in aliquot part of sample

\section{Lycopene content}

Lycopene content was determined by extracting 20 $\mathrm{g}$ of tomato juice, fresh or dry tomato in $100 \mathrm{~cm}^{3} 96 \%$ $\mathrm{C}_{2} \mathrm{H}_{5} \mathrm{OH}$. After $24 \mathrm{~h}$ of extraction (maceration), the sample was filtrated. The extract was evaporated to dryness. The dry extract was dissolved in $10 \mathrm{~cm}^{3}$ of mixture of acetone-hexane (ratio 4:6) and filtrated on WHATMAN No.4 paper. The obtained extract was dissolved 10 times and the absorbance was measured on wavelength 453, 505, 645 and 663nm (Nagata and Yamashita, 1992). Spectrophotometric measurements of samples have been performed by using UV-VIS spectrophotometer MA9523-SPEKOL 211 (Iskra, Horjul, Slovenia). The content of lycopene (mg lycopene/ $100 \mathrm{~mL}$ of extract) was calculated according to the equitation:

Lycopene $=$

$-0.0458 \times \mathrm{A} 663+0.204 \times \mathrm{A} 645+0.372 \times \mathrm{A} 505-0.0806 \times \mathrm{A} 453$

\section{Determination of $\beta$ carotene level}

$\beta$-Carotene was determined according to the method of (Nagata and Yamashita, 1992). The dried ethanol extract (100 mg tomato juice, fresh or dry tomato) was vigorously shaken with $10 \mathrm{ml}$ of acetonehexane mixture (4:6) for $1 \mathrm{~min}$ and filtered through WHATMAN No. 4 filter paper. The absorbance of the filtrate was measured at 453, 505, 645 and $663 \mathrm{~nm}$. Content of $\beta$-carotene was calculated according to the following equation:

$$
\begin{gathered}
\beta \text {-Carotene }(\mathrm{mg} / 100 \mathrm{ml})= \\
0.216 A_{663}-1,22 A_{645}-0.304 A_{505}+0.452 A_{453}
\end{gathered}
$$

\section{Total phenols content}

Total phenols in the tomato ethanol extracts $20 \mathrm{~g}$ tomato juice, fresh or dry tomato $100 \mathrm{~cm}^{3}$ in ethanol were estimated according to the Folin-Ciocalteu method (Singleton et al., 1999). The extract was diluted to the concentration of $1 \mathrm{mg} / \mathrm{mL}$, and aliquots of 0.5 
$\mathrm{mL}$ were mixed with $2.5 \mathrm{~mL}$ of Folin-Ciocalteu reagent (previously diluted 10-fold with distilled water) and $2 \mathrm{~mL}$ of $\mathrm{NaHCO}_{3}(7.5 \%)$. Aliquots were left for 15 minutes at 45 ${ }^{0} \mathrm{C}$, and then the absorbance was measured at $765 \mathrm{~nm}$ with a spectrophotometer against a blank sample. Gallic acid (GA) was used to calculate the standard curve. The assays were carried out in triplicate; the results were the mean values \pm standard deviations and expressed as $\mathrm{mg}$ of gallic acid equivalents per gram of dry extract (mg of $\mathrm{GA} / \mathrm{g}$ ).

\section{Total flavonoids content}

The aluminium chloride colorimetric method Brighente et al (2007) was used to measure the flavonoids content of the tomato extracts. $20 \mathrm{~g}$ tomato juice, fresh or dry tomato $100 \mathrm{~cm}^{3}$ in ethanol Two percent aluminium chloride $(0.5 \mathrm{~mL})$ in methanol was mixed with the same volume of methanol solution of plant extract. After 1 hourincubation at room temperature, the absorbance of the mixtures was measured at $415 \mathrm{~nm}$ using UV/VIS spectrophotometer. Rutin was used as the standard for the calibration curve. Estimation of the total flavonoids was carried out in triplicate. The results were mean values \pm standard deviations and expressed as rutin equivalents $(\mathrm{mg}$ of RU/g of dry extract).

Vitamin E

Vitamin E content was determined by using the photometric method according to Emmerie-Engel, with
$\mathrm{FeCl}_{3}$ and $\alpha, \alpha^{\prime}$-dipyridyl, which is based on the ability of tocopherol to reduce $\mathrm{Fe}^{3+}$ in $\mathrm{Fe}^{2+}$ which makes an intensive red coloured complex with $\alpha, \alpha^{\prime}$-dipyridyl. The intensity of colour was determined spectrophotometrically at $520-525 \mathrm{~nm}$.

\section{Total antioxidative activity}

Determination of total antioxidative activity by DPPH (1,1-Difenil-2-pikrilhidrazil) method has been done spectrophotometrically on $517 \mathrm{~nm}$.

\section{Dry matter weight}

The percentage of dry matter was determined by drying at $105^{\circ} \mathrm{C}$, till constant mass. After cooling in the desiccator from mass difference before and after drying and the known sample mass, percentage of dry matter was calculated.

\section{Statistical analysis (data analysis)}

Correlative ratio among the traits according to researched genotypes has been determined by applying Pearson matrix at the significance level $\mathrm{P} \leq 0.05$. The connection of genotypes and traits was done by multivariation technique of PCA-Principal Component analysis using Statistical software: XLSTAT Version 2012.4.02 Copyright Addinsoft 1995-2012. The analysis was performed according to average values of the researched parameters.

Table 1. The average values of bioactive components, as selection criteria for selection of seven genotypes of fresh and processed tomatoes

\begin{tabular}{|c|c|c|c|c|c|c|c|c|}
\hline $\mathrm{SPO}$ & S-60 & SPRM-20 & SPRZ & SPSM & SPP & SP-109 & $\begin{array}{l}\text { Genotypes / } \\
\text { treatments }\end{array}$ & $\begin{array}{l}\text { Bioactive } \\
\text { components }\end{array}$ \\
\hline 10.86 & 5.89 & 7.2 & 8.05 & 6.78 & 5.71 & 7.79 & Fresh (sv) & \multirow{3}{*}{$\begin{array}{l}\text { Vitamin C } \\
(\mathrm{mg} / 100 \mathrm{~g})\end{array}$} \\
\hline 5.05 & 4.25 & 5.54 & 6.53 & 5.20 & 4.10 & 4.21 & Dried (dr) & \\
\hline 5.37 & 2.75 & 3.52 & 3.62 & 3.25 & 2.69 & 3.80 & Juice (j) & \\
\hline 0.32 & 0.21 & 0.47 & 0.63 & 0.52 & 0.25 & 0.44 & Fresh (sv) & \multirow{3}{*}{$\begin{array}{l}\text { Vitamin E } \\
(\mathrm{mg} / 100 \mathrm{~g})\end{array}$} \\
\hline 0.21 & 0.14 & 0.28 & 0.50 & 0.35 & 0.15 & 0.31 & Dried (dr) & \\
\hline 0.14 & 0.08 & 0.24 & 0.33 & 0.28 & 0.09 & 0.22 & Juice (j) & \\
\hline 5.00 & 6.05 & 5.96 & 6.98 & 6.79 & 6.87 & 6.27 & Fresh (sv) & \multirow{3}{*}{$\begin{array}{l}\text { Lycopene } \\
\text { (mg/100g) }\end{array}$} \\
\hline 4.50 & 5.58 & 4.16 & 6.06 & 5.75 & 5.50 & 5.33 & Dried (dr) & \\
\hline 4.90 & 5.95 & 5.25 & 6.75 & 6.79 & 6.85 & 6.27 & Juice (j) & \\
\hline 0.85 & 0.53 & 0.35 & 0.75 & 0.56 & 0.40 & 0.43 & Fresh (sv) & \multirow{3}{*}{$\begin{array}{l}\beta \text {-carotene } \\
(\mathrm{mg} / 100 \mathrm{~g})\end{array}$} \\
\hline 0.30 & 0.39 & 0.25 & 0.42 & 0.29 & 0.27 & 0.30 & Dried (dr) & \\
\hline 0.68 & 0.49 & 0.30 & 0.70 & 0.55 & 0.40 & 0.43 & Juice (j) & \\
\hline 34.65 & 32.65 & 34.05 & 48.01 & 42.08 & 33.07 & 37.90 & Fresh (sv) & \multirow[t]{3}{*}{ Phenols (mgGAE/g) } \\
\hline 31.65 & 29.46 & 26.07 & 32.20 & 33.05 & 27.97 & 22.45 & Dried (dr) & \\
\hline 17.02 & 16.05 & 17.01 & 17.65 & 21.05 & 17.04 & 18.08 & Juice (j) & \\
\hline 13.76 & 12.98 & 15.45 & 18.25 & 17.04 & 13.27 & 15.44 & Fresh (sv) & \multirow[t]{3}{*}{ Flavonoids (mgRE/g) } \\
\hline 13.76 & 12.98 & 15.45 & 18.25 & 17.04 & 13.27 & 15.44 & Dried (dr) & \\
\hline 12.05 & 11.75 & 11.50 & 15.65 & 16.75 & 11.25 & 11.60 & Juice (j) & \\
\hline 4.75 & 4.95 & 4.78 & 4.55 & 5.20 & 4.25 & 4.70 & Fresh (sv) & \multirow[t]{3}{*}{ Dry matter $(\%)$} \\
\hline 17.00 & 16.25 & 18.05 & 16.25 & 19.05 & 18.05 & 18.25 & Dried (dr) & \\
\hline 4.70 & 4.88 & 4.64 & 4.20 & 4.98 & 3.37 & 3.70 & Juice $(j)$ & \\
\hline 12.00 & 11.04 & 13.25 & 15.05 & 14.15 & 11.05 & 13.05 & Fresh (sv) & \multirow{3}{*}{$\begin{array}{l}\text { Antioxidant activity } \\
\text { (mgAA/100g) }\end{array}$} \\
\hline 10.05 & 102. & 10.05 & 12.20 & 12.05 & 10.34 & 10.27 & Dried (dr) & \\
\hline 11.77 & 11.00 & 12.05 & 14.97 & 14.00 & 10.85 & 12.75 & Juice (j) & \\
\hline
\end{tabular}




\section{Results and Discussion}

Projection of variables according to Poarson correlation coefficient imply to high correlation of lycopene and $\beta$-carotene comparing to antioxidative activity of sample of fresh and proceeded tomato. Since total antioxidative activity was set as supplementing variable, lycopene and $\beta$-carotene had greater impacts on this activity, comparing to other researched parameters (phenols, flavonoids, vitamin $\mathrm{C}$ and vitamin $\mathrm{E}$ ).

Phenols, flavonoids and vitamin $\mathrm{C}$ were either not correlated or in low correlation with total antioxidative activity, since values went over negative part of coordinate system. Dry matter was not correlated with none of the researched traits. Second group of correlated nutritive parameters (vitamin $\mathrm{C}$, vitamin $\mathrm{E}$, phenols and flavonoids) had a strong correlative ratio but were in medium or low correlation with antioxidative activity (Figure 1).

Different nutritive components of tomato fruits behaved differently during processing. The level of vitamin C genotype depended on impact, climatic conditions, crop management, fertilizers, fruit development, maturation, and ways of processing (Toor et al., 2006; Borguini et al., 2013, Raiola et al., 2014), which in the co-ordination of these impacts provide more or less good quality raw material (tomato fruits) used in processing. In this experiment, the lycopene was relatively stable during thermal processing (drying or cooking) (Table 1). These results were in correlation with results of other authors (Sanchez-Moreno et al., 2006; George et al., 2001;
Demiray et al., 2013), but not with MartinezHernandez et al. (2016) who proved that the lycopene has decreasing stability with increasing the temperature of processing.

The difference in flavonoid content in dried sample and tomato juice, in this research can be contributed to to the thermal processing of fruits (Table 1). These results are in accordance with Dewanto et al. (2002) who proved that variation of total flavonoids in tomato fruits depend on thermal processing.

Level and the composition of the phenol compounds in tomato greatly depends on genotype (Caldwell et al., 2005; Frusciante et al., 2007; Garcia-Valverde et al., 2013; Raiola et al., 2014). During processing, after cooking, the level of phenols decreased for $1 / 2$, and during drying for 1/3 (Table 1).

The impact of genotype of carotene variation in tomato fruits was noted by Abushita et al. (2000), and Garcia-Valverde et al. (2013). Data of the analysed genotypes in this study confirmed that the concentration of $\beta$ - carotene could be very different in different tomato genotypes (Table 1). During processing of fruits the level of $\beta$-carotene was stable and did not have great losses.

Analysis of products obtained by thermal processing of tomato (drying and juice) in this study did not prove any statistically significant differences in total content of lycopene comparing to its content in fresh fruits, which proves its high thermal stability (Table 1). These results are in accordance with Sanchez-Moreno et al. (2006), George et al. (2001), and Demiray et al. (2013).

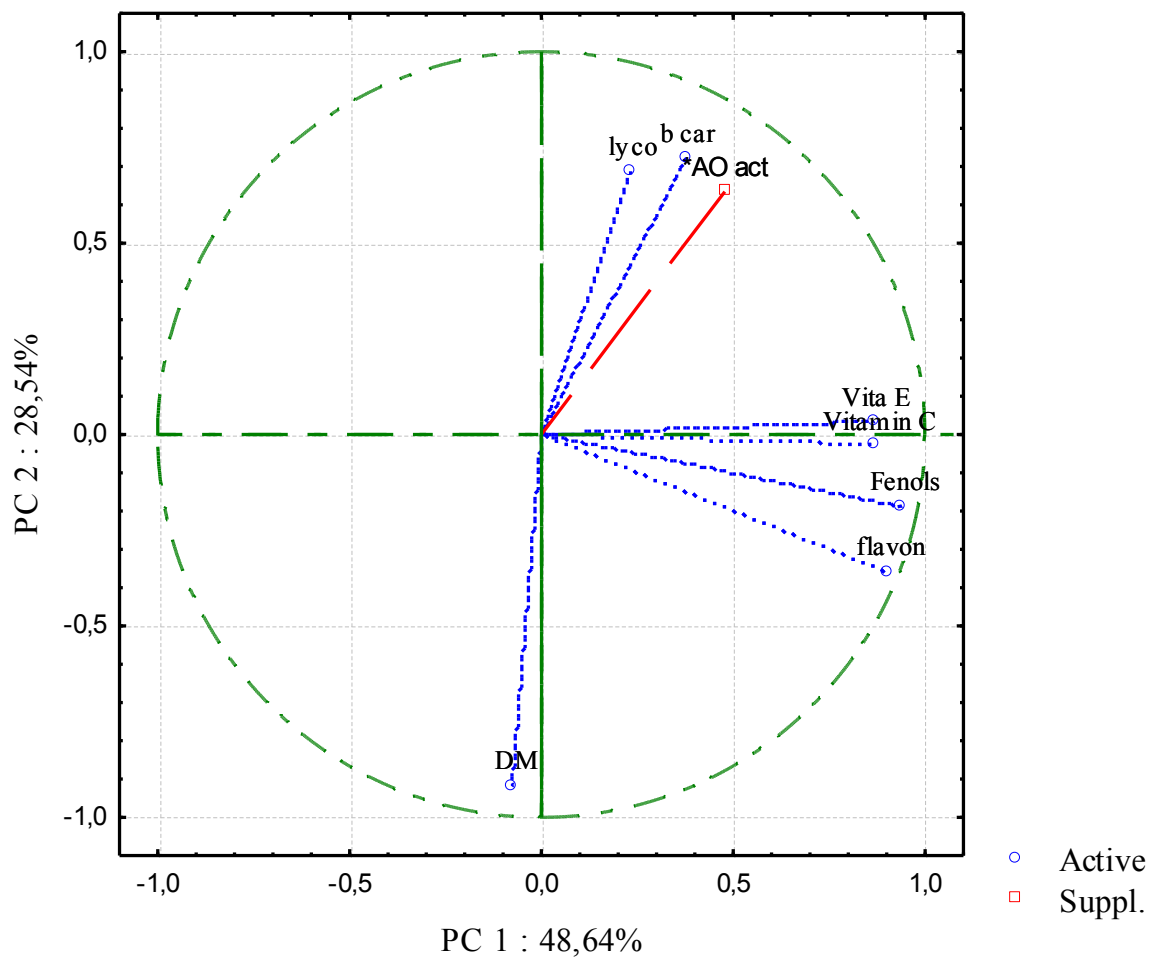

Figure 1. Pearson`s correlation figure of tested characteristics of tomato 
Table 2. Eigenvalues of seven principles components

\begin{tabular}{ccccc}
\hline $\begin{array}{c}\text { Cumulative } \\
\%\end{array}$ & $\begin{array}{c}\text { Cumulative } \\
\text { Eigenvalue }\end{array}$ & $\begin{array}{c}\text { \% Total } \\
\text { variance }\end{array}$ & Eigenvalue & \\
\hline 48.64 & 3.4049 & 48.64 & 3.4049 & 1 \\
77.18 & 5.4027 & 28.54 & 1.9978 & 2 \\
90.26 & 6.3184 & 13.08 & 0.9156 & 3 \\
94.70 & 6.6293 & 4.44 & 0.3109 & 4 \\
98.77 & 6.9139 & 4.07 & 0.2846 & 5 \\
99.62 & 6.9737 & 0.85 & 0.0597 & 6 \\
100.00 & 7.0000 & 0.38 & 0.0262 & 7 \\
\hline
\end{tabular}

Projection of variables according to Pearson correlation coefficient proved high correlation of lycopene and $\beta$-carotene comparing to total antioxidative capacities of fresh and processed tomato samples. The antioxidative activity was set as supplementing variable, so it can be concluded that the impact of lycopene and $\beta$-carotene was higher for this activity comparing to other researched bioactive components (phenols, flavonoids, vitamin $\mathrm{C}$ and vitamin $\mathrm{E}$ ). Phenols, flavonoids, vitamin $\mathrm{E}$ and vitamin $C$ either did not or were low correlated to total antioxidative activity, since values exceeded negative part of coordinate system. Dry matter was not correlated with noneof the researched trait. The second group of correlated nutritive parameters was vitamin C, vitamin $\mathrm{E}$, phenols and flavonoids, which were strongly correlated but middle or low correlated to total antioxidative activity (Figure 1). Graph shows clearly disjunctive traits that were relatively stable (lycopene and $\beta$-carotene) after thermal treatment and thermally labile traits (vitamin $\mathrm{C}$, vitamin $\mathrm{E}$, phenols and flavonoids), which means that in total impact on antioxidative complex they were more dominant, thermally stable components.

The first two principles components were responsible for $77.18 \%$ of total variability of researched samples. The impact of other five components was low and they were responsible for only $22.18 \%$ of variability (Table 2).

Table 3 shows which genotypes had significant impact on variability of the first two components. Genotypes SPSMsv, SPSMsv and SPOsv and S-60j had stronger impact on variation with negative sign. The first three genotypes had high level of nutrients in fresh fruits. The second main component was highly negatively impacted by genotypes: SPRM-20dr, SPOdr, which means that these genotypes had highest losses during drying, while SPRZj had the highest impact during juice preparation.

The first main component was highly influenced by phenols and flavonoids, vitamin $\mathrm{C}$ and vitamin $\mathrm{E}$, while lycopene and $\mathrm{b}$ carotene with positive values had the strongest impact on the second main component. While on the second main components the highest impact had

Table 3. Squared cosines of the observed genotypes and processing

\begin{tabular}{rrrrrrrc}
\hline PC 7 & PC 6 & PC 5 & PC 4 & PC 3 & PC 2 & PC 1 & \\
\hline-0.105 & 0.204 & 0.286 & -0.754 & -0.282 & 0.189 & 2.091 & SP-109sv \\
-0.031 & 0.241 & -0.558 & -0.862 & -0.930 & 0.692 & 0.546 & SPPsv \\
0.048 & -0.292 & 0.019 & -0.007 & -0.811 & 0.706 & $\mathbf{2 . 7 5 8}$ & SPSMsv \\
-0.124 & -0.436 & -0.050 & 0.555 & -0.411 & 1.308 & 4.132 & SPRZsv \\
0.210 & 0.021 & 0.909 & -0.868 & -0.149 & -0.341 & 1.649 & SPRM-20sv \\
0.123 & -0.168 & -0.706 & -0.544 & 0.228 & 0.544 & 0.433 & S-60sv \\
-0.089 & 0.398 & -0.377 & 0.003 & 2.933 & 0.803 & 2.366 & SPOsv \\
0.084 & 0.158 & 0.309 & 0.807 & -0.183 & -1.499 & -0.845 & SP-109dr \\
-0.206 & 0.070 & -0.650 & 0.037 & -0.422 & -1.735 & -1.114 & SPPdr \\
0.277 & 0.146 & -0.260 & 0.333 & -0.881 & -2.013 & 0.747 & SPSMdr \\
0.048 & 0.433 & 0.410 & 0.777 & -0.599 & -1.060 & 1.576 & SPRZdr \\
-0.066 & -0.071 & 0.590 & -0.034 & 0.804 & -2.573 & -0.675 & SPRM-20dr \\
-0.085 & -0.120 & -0.948 & 0.194 & -0.115 & -1.194 & -0.801 & S-60dr \\
-0.184 & -0.439 & -0.178 & -0.169 & 0.573 & -2.231 & -0.516 & SPOdr \\
-0.147 & 0.152 & 0.403 & -0.219 & -0.283 & 1.147 & -1.713 & SP-109j \\
-0.123 & 0.258 & -0.368 & -0.378 & -0.893 & 1.428 & -2.444 & SPPj \\
0.135 & -0.065 & 0.024 & 0.479 & -0.730 & 1.517 & -0.997 & SPSMj \\
-0.190 & 0.002 & 0.383 & 1.141 & -0.096 & 2.274 & -1.133 & SPRZj \\
-0.111 & -0.215 & 1.108 & -0.581 & 0.135 & 0.104 & -2.153 & SPRM-20j \\
0.313 & -0.154 & -0.344 & -0.104 & 0.100 & 0.996 & -2.415 & S-60j \\
0.226 & -0.124 & 0.001 & 0.203 & 2.017 & 0.936 & -1.491 & SPOj \\
\hline
\end{tabular}


Table 4. Squared cosines of the observed traits

\begin{tabular}{|c|c|c|c|c|c|c|c|}
\hline PC 7 & PC 6 & PC 5 & PC 4 & PC 3 & PC 2 & PC 1 & \\
\hline-0.040 & 0.162 & 0.014 & -0.137 & 0.439 & -0.029 & 0.871 & Vitamin C \\
\hline-0.021 & 0.098 & -0.149 & 0.058 & -0.660 & 0.688 & 0.230 & Lycopene \\
\hline-0.006 & -0.024 & 0.413 & 0.196 & -0.202 & 0.031 & 0.865 & Vitamin E \\
\hline-0.082 & -0.131 & -0.180 & -0.115 & -0.109 & -0.186 & 0.939 & Fenols \\
\hline 0.126 & 0.002 & -0.129 & -0.055 & -0.141 & -0.358 & 0.903 & Phlavonoids \\
\hline-0.032 & 0.058 & -0.133 & 0.357 & -0.082 & -0.915 & -0.073 & Dry mater \\
\hline 0.018 & -0.045 & -0.155 & 0.325 & 0.453 & 0.721 & 0.374 & $\beta$ carotene \\
\hline 0.003 & -0.129 & 0.374 & 0.255 & -0.194 & 0.634 & 0.477 & AO* actitvity \\
\hline
\end{tabular}

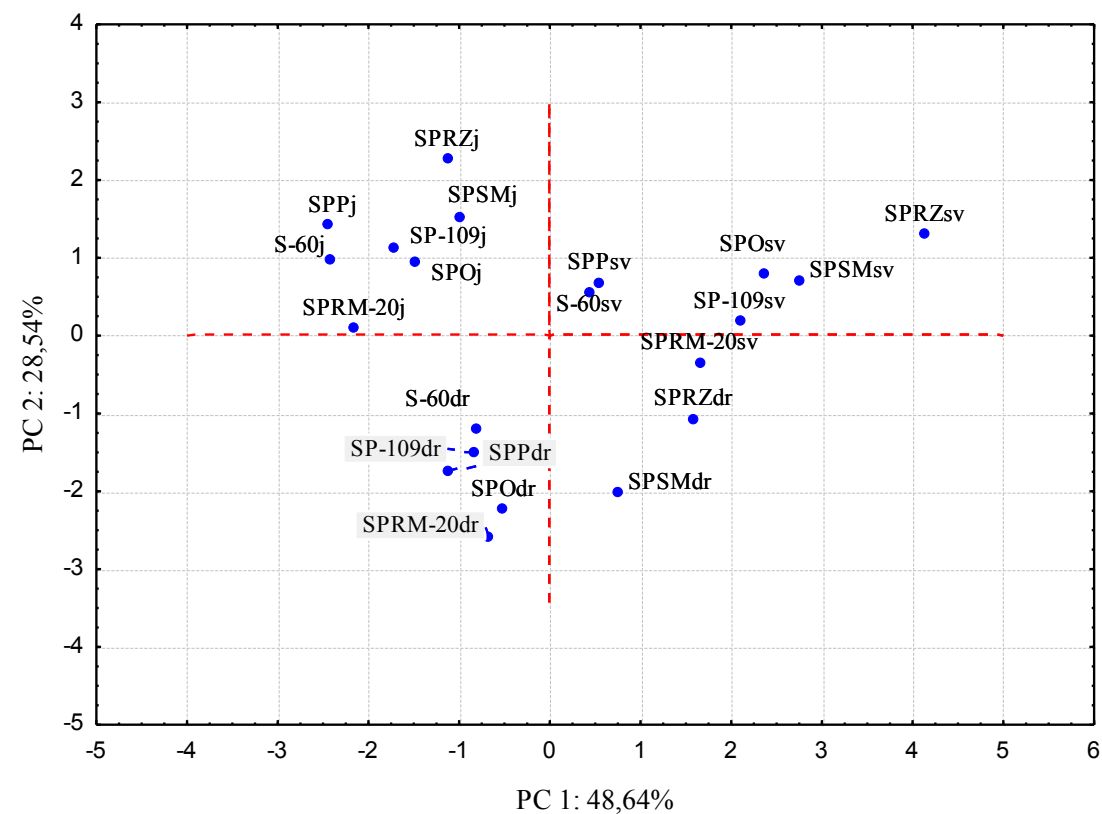

Figure 2. PCA analysis biplot of first and second principles component

lycopene and $\beta$-carotene with positive and dry matter with negative values (Table 4).

According to Figure 2, genotype with highest eigenvalue for all researched parameters was fresh SPRZ. It is quite logical that the products of this genotype contain most nutrients, so that the juice as SPRZj holds the position of the quadrant II, from the beginning of the coordinate system, which represents a high average value, for all tested characteristics. The best lines for drying were SPRZdr and SPSMdr at the position in the quadrant IV and somewhat separated from a group of nutritional parameters of dried tomato. According to determined values these two genotypes had the lowest losses and were the best after drying process.

De Nardo et al. (2009) compared two methods for lycopene determination by applying PCA multi variation technique and found same grouping of genotypes as in this research. However, the results of this multi variation model depend on the number of traits and trail demand design in researched cases, where Lavelli et al. (2001) found that the first two components were 78 $\%$ responsible for sample variance, where the first component was $60 \%$ and the second $18 \%$.

\section{Conclusions}

Two lines (SPRZ and SPSM) with the best final products were chosen for further selection process and research of combining abilities.

In this study, the dependence of high temperature and bioactive nutrients was confirmed. Losses were higher in high temperatures (juice production) comparing to temperatures for drying. 


\section{References}

Abushita, A., Daood A. and Biacs P. A. (2000): Change in carotenoids and antioxidant vitamins in tomato as a function of varietal and technological factors. Journal of Agricultural and Food Chemistry 48, 2075-2081.

Asami D.K., Hong Y.J., Barrett D.M. and Mitchell A.E. (2003): Processing induced changes in total phenolics and procyanidins in clingstone peaches. Journal of the Science of Food and Agriculture 83, 56-63.

Basavaraja N. and Hulamani N.C. (2001): Correlation studies for quantitative characters in chilli (Capsicum annum L.). 11th Meeting on genetics and breeding of capsicum and eggplant, Antalya, Turkey, 9 (13), 43-46.

Borguini, G. R., Markowicz D. H., Moita-Neto J. M., Capasso F. S. and Torres E. A. (2013): Antioxidant potential of tomatoes cultivated in organic and conventional systems. Brazilian Archives of Biology and Technology 56, 521-529.

Brighente I.M.C., Dias M., Verdi L.G. and Pizzolatti M.G. (2007): Antioxidant activity and total phenolic content of some Brazilian species. Pharmaceutical Biology, 45, 156-161.

Caldwell C.R., Britz S.J. and Mirecki R.M. (2005): Effect of temperature, elevated carbon dioxide, and drought during seed development on the isoflavone content of dwarf soybean (Glycine $\max$ L.) Merrill) grown in controlled environments. Journal of Agricultural and Food Chemistry 53, 1125-1129.

Canene-Adams K., Campbell J.K., Zaripheh S., Jeffery E.H. and Erdman J.W. (2005): The tomato as a functional food. Journal of Nutrition 135, 1226-1230.

Carrari, F., C. Baxter, B. Usadel, E. Urbanczyk-Wochniak, M. I. Zanor, A. Nunes-Nesi, V. Nikiforova, D. Centero, A. Ratzka, M. Pauly, L. J. Sweetlove and A. R. Fernie (2006): Integrated analysis of metabolite and transcript levels reveals the metabolic shifts that underlie tomato fruit development and highlight regulatory aspects of metabolic network behavior. Plant Physiology, 142, 1380-1396.

Cvijović M. and Aćamović-Đoković G. (2005): Praktikum iz biohemije. Agronomski fakultet, Čačak (in Serbian).

Davey M.W., Van Montagu M., Inze D., Sanmartin M., Kanellis A., Smirnoff N., Benzie I.J.J., Strain J.J., Favell D. and Fletcher J. (2000): Plant l-ascorbic acid: chemistry, function, metabolism, bioavailability, and effects of processing. Journal of the Science of Food and Agriculture 80, 825-860.

De Nardo Th., Shiroma-Kian C., Halim Y., Francis D. and RodriguezSaona L. (2009): Rapid and Simultaneous Determination of Lycopene and $\beta$-Carotene Contents in Tomato Juice by Infrared Spectroscopy. Journal of Agricultural and Food Chemistry 57 (4), 1105-1112

Demiray E., Tulek Y. and Yilmaz Y. (2013): Degradation kinetics of lycopene, $\beta$-carotene and ascorbic acid in tomatoes during hot air drying. LWT - Food Science and Technology 50, 171-176.

Dewanto V., Wu X., Adom K. K. and Liu R. H. (2002): Thermal Processing Enhances the Nutritional Value of Tomatoes by Increasing Total Antioxidant Activity. Journal of Agricultural and Food Chemistry 50, 3010-3014.

Foolad M. R. (2007): Genome mapping and molecular breeding of tomato. International Journal of Plant Genomics. Article ID 64358, 52 pages doi:10.1155/2007/64358

Frusciante L., Carli P. and Ercolano M. R. (2007): Antioxidant nutritional quality of tomato. Molecular Nutrition and Food Research 51(5), 609-617.

Ganeva D., Ivanova I. and Pevicharova G. (2006): Identification of determinate tomato $F_{1}$ hybrids using cluster analysis. Proceedings of the First International Symposium Ecological Approaches towards the Production of Safety Food, 19-20 of October, Plovdiv, Bulgaria, 205-210.

Garcia-Valverde V., Navarro-Gonzales I., Garc'ia-Alonso J. and Periago M. J. (2013): Antioxidant bioactive compounds in selected industrial processing and fresh consumption tomato cultivars. Food and Bioprocess Technology 6(2), 391-402.
George S., Tourniaire F., Gautier H., Goupy P., Rock E. and CarisVeyrat C. (2011): Changes in the contents of carotenoids, phenolic compounds and vitamin $\mathrm{C}$ during technical processing and lyophilisation of red and yellow tomatoes. Food Chemistry 124, 1603-1611.

Hinneburg I. and Neubert R.H., (2005): Influence of extraction parameters on the phytochemical characteristics of extracts from buckwheat (Fagopyrum esculentum) herb. Journal of Agriculture and Food Chemistry 53, 3-7.

Lavelli V., Pagliarini E., Giovanelli G., Peri C. and Zanoni B. (2001): The antioxidant activity of tomato. I. Evaluation of fresh and processed products by chemical-physical indexes and biochemical model systems through principal component analysis. Acta horticulture (ISHS) 542, 205-210

Martınez-Hernandez B. Boluda-Aguilar G., Taboada-Rodriguez M., Soto-Jover A., Marın-Iniesta S.F. and Lopez-Gomez A. (2016): Processing, Packaging, and Storage of Tomato Products: Influence on the Lycopene Content. Food Engineering Reviews $8(1), 52-75$.

Mukhopadhyay S., Luthria D.L. and Robbins R.J., (2006): Optimization of extraction process for phenolic acids from black cohosh (Cimicifuga racemosa) by pressurized liquid extraction. Journal of the Science of Food and Agriculture 86, 156-162.

Nagata M. and Yamashita I. (1992): Simple method for simultaneous determination of chlorophyll and carotenoids in tomato fruit. J. Food Sci. Technol. 39, 925-928.

Pék Z. , Szuvandzsiev P., Daood H., Neményi A. and Helyes L. (2014): Effect of irrigation on yield parameters and antioxidant profiles of processing cherry tomato. Cent. Eur. J. Biol. 9(4), 383 $-395$.

Periago M. J., Garc'1a-Alonso J. and Jacob K. (2009): "Bioactive compounds, folates and antioxidant properties of tomatoes (Lycopersicum esculentum) during vine ripening," International. Journal of Food Sciences and Nutrition 60(8), 694-708.

Raiola A., Rigano M. M., Calafiore R., Frusciante L. and Barone A. (2014): Enhancing the Health-Promoting Effects of Tomato Fruit for Biofortified Food. Mediators of Inflammation, ID 139873, 16 pages.

Ruggieri V., Bostan H., Barone A., Frusciante L. and Chiusano M.L. (2016): Integrated bioinformatics to decipher the ascorbic acid metabolic network in tomato. Plant molecular biology, pp.1-16.

Sanchez-Moreno C., Plaza L., de Ancos B. and Cano M. P. (2006): Impact of highpressure and traditional thermal processing of tomato puree on carotenoids, vitamin $\mathrm{C}$ and antioxidant activity. Journal of the Science of Food and Agriculture 86(2), 171-179.

Seybold C., Frohlich K., Bitsch R., Otto K. and Bohm V. (2004): Changes in contents of carotenoids and vitamin $\mathrm{E}$ during tomato processing, Journal of Agricultural and Food Chemistry, 52, 7005-7010

Tedeschi P., Coïsson J. D., Maietti A., Cereti E., Stagno C., Travaglia F., Arlorio M., and Brandolini V. (2011): Chemotype and genotype combined analysis applied to tomato (Lycopersicon esculentum Mill.) analytical traceability. Journal of Food Composition and Analysis, 24, (2), 131-139.

Toor R. K., Savage G. P. and Heeb A. (2006). Influence of different types of fertilizers on the major antioxidant components of tomatoes. Journal of Food Composition and Analysis, 19, 20-27.

Trajković J., Baras J., Mirić M. and Šiler S. (1983): Analiza životnih namirnica, Beograd.

Xu F., Li L., Huang X., Cheng H., WangY. and Cheng S. (2010): Antioxidant and antibacterial properties of the leaves and stems of Premna microphylla. J. Med.Plants Res. 4(23), 2544-2550. 


\section{Bioaktivne komponente u funkciji oplemenjivanja industrijskog paradajza}

\section{Nenad Pavlović · Jelena Mladenović - Radoš Pavlović. Đorđe Moravčević · Jasmina Zdravković}

Sažetak: Selekcija linija paradajza namenjenog industrijskoj preradi prema osobinama koje definišu njihovu nutritivnu vrednost predstavljaju potencijal koji će se reflektovati u proizvodu dobijenom od plodova paradajza. U isto vreme ispitan je i tehnološki proces pripreme soka paradajza $\left(100^{\circ} \mathrm{C}\right)$ kao i sušenje plodova na toplom vazduhu, kako bi se utvrdio optimalni tehnološki proces koji najmanje narušava prirodni potencijal nutrijenata sadržanih u svežim plodovima. Ispitivanje je sprovedeno na 6 linija i jednoj sorti industrijskog paradajza gde su ispitani sadržaj vitamina C, vitamina E, likopina, $\beta$-carotina, fenola, flavonoida, suve materije i ukupni antioksidativni kapacitet, standardnim metodama za utvrđivanje sadržaja ovih parametara. Grupisanje je izvršeno prema osobinama prosečnog sadržaja karetinoida (likopen, $\beta$-karoten), vitamina $C$, vitamina $E$, fenola, flavonoida, suve materije i ukupnog antioksidatinog kapaciteta u plodu paradajza, pomoću PCA analize. Prve dve principle komponente odgovorne su za 77,18\% ukupne varijabilnosti ispitivanih uzoraka. Uticaj ostalih pet komponenti je mali i one su odgovorne za 22,18\% varijabilnosti. Antioksidativna aktivnost je najbolje očuvana posle dorade kroz male gubitke likopina i $\beta$-karotina posle dorade. Gubici vitamina C, vitamina E, fenola, flavonoida pri termičkoj obradi su veliki i to najviše u soku, dok kod sušenog proizvoda ti gubici su nešto manji. Gubici nutrijenata su u funkciji visine temperature kojima su plodovi bili izlagani pri termičkoj obradi. Kao najbolji genotipovi ocenjeni su SPRZ i SPSM.

Ključne reči: industrijski paradajz, selekcione linije, PCA, antioksidativna aktivnost, nutrijenti 